\title{
Mīmāṃsāsūtra and Brahmasūtra
}

\author{
Johannes Bronkhorst
}

Published online: 9 March 2014

(C) Springer Science+Business Media Dordrecht 2014

Vedānta as a philosophical school does not appear in sources belonging to traditions different from itself until late, presumably not before the second half of the first millennium CE. This point is not, as far as I can see, contested in scholarly literature.

A different, though related, issue is whether the fundamental text of Vedānta philosophy, the Brahmasūtra, is as old as the Mìmānsāsütra; if so, it was presumably already in existence centuries before Vedānta as a philosophical school is noticed in philosophical texts of other schools. This is a different issue, because it is conceivable that the Brahmasutra existed and was preserved in circles that did not participate in philosophical confrontations. ${ }^{1}$ These circles may then have held a more or less secret doctrine that resembled in certain respects the Vedānta philosophy that was still to be created. On this hypothesis, this doctrine did not wish to interact with the different philosophical schools, and may have been the isolated property of certain Brahmanical groups that did not bother, or wish, to systematize it $^{2}$ or wish to test its mettle in confrontations with other thinkers. ${ }^{3}$ All this is conceivable, but does not affect the observation that philosophical Vedānta, i.e.

\footnotetext{
1 There is barely a sūtra in the Brahmasūtra which has no variant readings, and this process of diversification had already begun before Śankkara; see Bapat (2011: xxvii f).

2 Cf. Aklujkar (2001): 461: "Strictly speaking, Bhartṛhari is not a Vedāntin ... It would be more accurate to speak of Bhartrhari as a Trayyanta-vedin, a term having a close connection with Vedāntin but coming from a period in which Vedānta was not a system or school." (my emphasis, JB).

3 Aklujkar (2011: $850 \mathrm{f}$ ). draws attention to the expressions pratisaṃkyānirodha, apratisaṃkyānirodha and ksanikatva in the Brahmasütra. These are Buddhist terms, but not only that. They are terms that belong to the Abhidharma developments of north-western India that are associated with the Sarvāstivādins: pratisamkhyānirodha and apratisaṃkhyānirodha are two of their asamskrta dharmas, and momentariness (kșanikatva) is a doctrine they introduced (see Bronkhorst 2009: 82 ff., 93). These developments in Abhidharma date already to a time preceding the Common Era. The presence of these
}

J. Bronkhorst ( $($ )

Lausanne, Switzerland

e-mail: johannes.bronkhorst@unil.ch 
systematized Vedānta, did not appear in the court of debating and comparing philosophers until roughly the second half of the first millennium CE.

Much more weighty is the claim that Mìmānsāsūtra and Brahmasūtra were originally parts of one single work. It would suggest that the followers of the Mìmāmsāsūtra were also followers of the Brahmasütra, at least during the early period. In other words, there was a time when ritual Mīmāṃsakas were Vedāntins and vice versa.

In an earlier publication (2007) I have argued that Mìmāmsāsūtra and Brahmasütra were not originally parts of one single work. This position has now been criticized by Aklujkar (2011). The present article will consider some of his arguments. 4

Note to begin with that we have no direct early evidence for the existence of a combined Mìmāms $\bar{a}-+$ Brahma-sūtra. Our primary sources of information are commentaries and independent works, mainly of Vedānta allegiance, and all dating from the time after the appearance of Vedānta as a philosophical school. Most of these texts look upon Vedānta as a form of Mīmāṃsā, so their authors were a priori inclined to look upon the Brahmasūtra as a Mīmāmsāa text. The need to justify their Vedānta as being on a par with traditional Mīmāṃsā must have made it attractive to believe that the Brahmasutra once was part of a single work which also contained the Mìmāmsāsūtra. And yet this is not what we find in all the relevant sources.

As a first approximation, we may think that a single work has a single author. As a matter of fact, Sureśvara, presumably a direct pupil of Śankara, thought that Mìmāmsāsūtra and Brahmasūtra did indeed have a single author. To cite Aklujkar (p. 829), "one just cannot doubt that Sureśvara thought of Jaimini as involved in the composition of both the sūtra groups, one beginning with athāto dharma-jijjñas $\bar{a}$ [i. e., what we now call the Mìmānsāsūtra, JB] and the other with athâto brahmajijñ̄as $\bar{a}$ [the Brahmasūtra, JB]". Aklujkar rejects attempts "to undermine Sureśvara's credibility”, and clearly considers Sureśvara's testimony reliable. ${ }^{5}$

However, the Prapañcahrdaya, a text of uncertain date, ${ }^{6}$ contains a passage that speaks of a Mìmāmsāásāstra consisting of twenty adhyāyas. Aklujkar accepts "the fact that the passage mentions Jaimini as the author of the first sixteen adhyāyas and Vyāsa ... as the author of the remaining four adhyāyas" (p. 828). He then asks: "Could the absence of associating Jaimini with the last four adhyāyas and the absence of associating (Bādarāyaṇa) Vyāsa with the first sixteen adhyāyas not be based ... on the information the Prapañca-hrdaya author had about the primary authors of the particular parts?" This appears to mean that the different parts of this

Footnote 3 continued

terms in the Brahmasütra tells us therefore little about its date, but it does suggest that the text belonged to a less isolated milieu than one might think.

4 Aklujkar's critiques are "largely ... philological in nature, based as they are on actual textual evidence" (p. 879). This means that he overlooks Mīmāmsāā's self-understanding, which is yet a vital issue in this discussion, as will be shown below.

5 On p. 878 Aklujkar states that Sureśvara "must have known that Bādarāyaṇa authored the [Brahmasūtra]". More on this below.

${ }^{6}$ See Bronkhorst (2007: 20 n. 27, 64 n. 98). 
presumably single text had different primary authors. Put differently, two parts, composed by two different authors, had been put together. Or more straightforward: two texts, composed by two different authors, had been combined. If the Prapañcahrdaya is right, these two parts subsequently became parts of one single text. The Prapañcahrdaya provides no information as to when this supposedly happened. It leaves all options open, such as: the two texts were composed more or less simultaneously and joined soon after; or they were composed simultaneously but joined much later; or they were not composed simultaneously at all and were joined some time after the composition of the more recent one of the two. In spite of this, Aklujkar asks: "Is there any word in [the] statement [of the Prapañca-hrdaya author] that conveys the idea of 'combining' or 'efforts at combining'?" The answer to this question is, of course, that there is not just a word that conveys this idea, but that the whole statement does so.

Like the Prapañcahrdaya, Padmapāda, presumably another pupil of Śankara, appears to distinguish between the author of the Mìmāmsāsūtra, Jaimini, and the author of the Brahmasūtra, here called Bādarāyaṇa. Aklujkar comments (p. 833): "I fail to see how Bronkhorst can be certain that Padma-pāda disagrees with Sureśvara on the matter of authorship of the [Brahmasūtra]." Unfortunately, in philology one is rarely certain, if ever. One makes the best of sometimes difficult and ambiguous statements, knowing that even simple statements may allow of multiple interpretations. One is guided by the knowledge that some interpretations are closer to the text than others. However, the difficulties that habitually harass the philologist are almost completely absent in Padmapāda's passage. It reads, in Aklujkar's translation (p. 833):

Revered Jaimini affirmed dharma only as the object of his reasoned exploration. He applied himself to that domain (of dharma) only. He did not seek to determine where and how the (aforementioned) knowing (or attainment) of own nature (exists/comes about), for (such a determination) had no use (for him, that is, in the domain he chose for his reasoned exploration). On the other hand, revered Bādarāyaṇa, having announced his intention to accomplish (pratijñāya) a separate reasoned exploration, carried out that exploration with the sasstra consisting of reconciling (the statements in the Veda or Veda-conclusion texts). ${ }^{7}$

At first sight we find here the same division we also found in the Prapañcahrdaya. Two authors are involved: Jaimini, presumably as author of the Mìmānsāsūtra, and Bādarāyaṇa, as author of the Brahmasūtra.

Aklujkar does not like this straightforward interpretation, nor indeed the glaring opposition between Prapañcahrdaya and Padmapāda on one hand, and Sureśvara on the other. In order to resolve it, he states that "we should note that in making such a statement, Padma-pāda is not saying that Jaimini had no hand in shaping the

\footnotetext{
7 Pañcapādikā of Padmapāda, ed. S. Śrīrāma Śāstrī \& S. R. Krishnamurthi Śāstrī, pp. 149-150: sa ca svarūpāvagamaḥ kasmin katham veti dharmamātravicāram pratijñāya tatraiva prayatamānena bhagavatā jaimininā na mīmāmsitam upayogābhāvāt, bhagavāṃs tu punar bādarāyaṇah pṛthakvicāram pratijñāya vyacīcarat samanvayalakșaṇena.
} 
Sārīraka, that is, the [Brahmasūtra]". Indeed, Aklujkar proposes to look upon all three texts as providing reliable information, by making the assumption that Jaimini, while being the primary author of the Mìmāmsāsūtra, helped Vyāsa Bādarāyaṇa in composing the Brahmasütra. He can therefore state that "there is a consistent record in our ... sources ... to the effect that the [Mìmāmsāsütra] and [Brahmasütra] are to be treated as one would treat two volumes of a connected text, ascribed, as volumes, to two different authors" (p. 846). In other words, two authors composed two texts (but not without helping each other), that were to be incorporated in one single work that they had planned together. ${ }^{8}$ These two authors worked simultaneously. ${ }^{9}$ Indeed, "If [the] attempt to disprove the traditional assumption of the contemporaneity of Jaimini and Vyāsa/Bādarāyaṇa is considered successful, the possibility that [Mìmāmsāsūtra] and [Brahmasūtra] were planned as a continuum must be discarded" (p. 861). ${ }^{10}$ Aklujkar does not consider this attempt successful. In his opinion, the single work of which Mìmānsāsūtra and Brahmasūtra were once parts, was the result of joint authorship (pp. 887-889).

Clearly Aklujkar weaves an elaborate speculative network with the purpose of eliminating a rather obvious contradiction in the three texts considered. What is his evidence? None whatsoever, except possibly "the fact that Jaimini and Bādarāyaṇa quote each other" (p. 861). Given the fact that the three texts ascribe the authorship of the Brahmasūtra to three different authors-Jaimini, Bādarāyana and Vyāsa-(or at least give different names to its author) reduces the value of this evidence practically to naught.

I am confident that many philologists, like me, will shudder when confronted with the speculative reconstruction of the lives and joint activities of personsJaimini and Bādarāyana — on the basis of so little evidence. This reconstruction is yet necessary to maintain Aklujkar's main thesis, viz., that Mìmāmsāsūtra and Brahmasūtra were originally part of a single text. If we do not accept this reconstruction, the thesis collapses. As Aklujkar puts it (see above): "If [the] attempt to disprove the traditional assumption of the contemporaneity of Jaimini and Vyāsa/ Bādarāyaṇa is considered successful, the possibility that [Mìmānsāāutra] and [Brahmasūtra] were planned as a continuum must be discarded" (p. 861). It looks indeed wise to discard it.

Quite apart from what Aklujkar may think of it, the passages so far considered represent two different positions. According to Sureśvara, Mīmāmsāāūtra and Brahmasütra were originally part of one single work, with one single author; according to Padmapāda and the Prapañcahrdaya, the two had two different authors, and were originally therefore not part of one work. In the latter case, these

\footnotetext{
${ }^{8}$ P. 877: "Where I ... go beyond [Parpola] is that I hold that the text pair was planned to form a unity".

${ }^{9}$ In a more recent article Aklujkar (2013) goes even further, claiming that the team consisted not of just two, but of three authors: Jaimini the author of the Mìmāmsāsūtra, Bādarāyana the author of the Brahmasūtra, and Kāśakṛtsna the author of the Sañkarșakāṇ̣a that is/was situated between the former two texts.

10 Also p. 878: "I have strong reservations about accepting the conclusion that Bādarāyana is later than Jaimini”.
} 
two works may have been combined at some point in time, but our passages do not tell us when this happened (if it happened at all).

With this in mind, and remembering the difficulties of interpretation that meet philological work at every step, we may consider the passage in Śankara's Brahmasūtrabhāṣya that Aklujkar discusses in detail. The passage is obscure and lends itself to different interpretations. Earlier scholars - to begin with Jacobiinterpreted it in a manner that presupposed that, in Śankara's opinion, Mìmāmsāsūtra and Brahmasütra were one single text. Other scholars, from Keith onward, demurred, and my own publication (2007: $6 \mathrm{ff}$.) shows that the passage allows of a satisfactory interpretation that is not based on that presupposition. Aklujkar criticizes this interpretation, but does in the end no more than stating that an interpretation is possible in which Jacobi's presupposition is maintained. This, of course, is nothing new.

Aklujkar's discussion of this and related matters is marred by a fundamental misunderstanding of what Mīmāmsāa is. ${ }^{11}$ This comes out clearly in the following passage (p. 845):

It should be amply clear ... that there was really no adequate justification for Bronkhorst's attempt to show how Vedānta joined hands with Mīmāṃsā at a later time-how there were first non-Mīmāṃsaka Vedāntins and later ... Mīmāmssaka Vedāntins. The forced nature of the attempt becomes further evident even if we ask only the following question: Why would the specified thinkers try to move near ritual Mīmāmssā when they were not all that enthusiastic about ritual and had inherited a long tradition of seeing only a limited utility in ritual and of interpreting ritual metaphorically ...

What then is Bronkhorst's justification even for speaking of later Vedāntins as anxious to be seen, additionally, as Mīmāmsakas or as well-versed in Mīmāṃsā? It may be located in his statement on p. 23: “... at least some Vedāntins at some point ... made a[n] effort to turn themselves into, or become recognized as, some kind of Mīmāmsakas, different from the ritual Mīmāṃsakas ... because these Vedāntins, too, followed the same strict rules of Vedic interpretation as the ritual Mīmāmsakas."

Aklujkar's confusion is partly due to the unfortunate expression "ritual Mīmāmsāa" (which I use, too). It suggests that Mīmāṃsakas were interested in ritual. Strictly speaking, and seen from their own theoretical perspective, they were not. Mīmāṃsakas studied the eternal Veda, using refined tools of interpretation, and it turned out that the Veda told them to perform rituals. At least theoretically, their ritual activities were not the result of their interest in ritual, but the outcome of their study of the infallible Veda. Had their interpretational efforts convinced them that the Veda told them to play tennis, ${ }^{12}$ they would then have played tennis, whether they liked it or not.

\footnotetext{
${ }^{11}$ Mīmāmsā clearly presents great difficulties of understanding for modern scholars. For a discussion of another misunderstanding, see Bronkhorst (1998).

12 Those who find this possibility farfetched may recall that Dharmakīrti proposes to interpret the injunction agnihotram juhuyāt svargakämah as "One should eat dog meat" (Eltschinger et al. 2012: 24, $41)$.
} 
The Vedāntic Mīmāṃsakas, such as Śankkara, pointed out that the correct and consistent application of the Mīmāmsā principles of interpretation did not only reveal the obligation to sacrifice. It also revealed knowledge of Brahma as means of liberation. Theoretically, the Vedāntic Mīmāmsakas were no more interested in Brahma than the "ritual" Mīmāṃsakas were interested in ritual. In both cases they did no more than interpreting the Veda correctly. Both were Mīmāmsakas, with the proviso that the Vedāntins concerned considered themselves even better Mīmāṃsakas than the others, because they applied the same principles in a more thorough manner. The question "Why would Vedāntins try to move near ritual Mīmāṃsā when they were not all that enthusiastic about ritual?" betrays in this manner a fundamental misunderstanding and misappreciation of Mīmāmssā. No one-not even the "ritual Mīmāmsakas"—was enthusiastic about ritual, at least in theory. And the Vedāntins concerned were not interested in ritual, but all the more in showing that their position was based on the correct interpretation of the Veda, i.e., with the help of the principles elaborated by "ritual" Mīmāmsā.

It should now be clear that certain Vedāntins were keen to be considered Mīmāmsakas, interpreters of the Veda who derive their positions directly from the Veda rather than speculators about the absolute. Aklujkar is therefore right in stating that "there is a consistent record in our ... sources ... to the effect that the [Mìmāmsāsūtra] and [Brahmasūtra] are to be treated as one would treat two volumes of a connected text" (p. 846). The advantage of this position for Vedānta thinkers is obvious: their position is as close to the Veda, if not more so, than that of the traditional Mīmāmsakas.

What can we conclude from this short discussion? First of all, that there is no compelling evidence to show that Mìmāmsāsūtra and Brahmasūtra were originally part of one single text. Second, the wish of certain Vedāntins to be looked upon as serious Mīmāmsakas rather than as idle speculators makes sense (and is confirmed by textual evidence discussed in my 2007 article). The claim by certain Vedāntins that the Brahmasūtra was originally part of a larger text that also included the Mìmāmsāsūtra is therefore understandable. It is even possible that Mìmāmsāsūtra and Brahmasūtra were actually joined by some (with the Sankarșakānda in between), and that commentaries were written on the whole. This does not however mean that this represented the original situation, with the implication that from the beginning Mīmāmsakas were, in their heart of hearts, Vedāntins by conviction. This notion should be abandoned, because it merely adds confusion to our understanding of the history of Indian thought.

\section{References}

Aklujkar, A. (2001). The word is the world: Nondualism in Indian philosophy of language. Philosophy East \& West, 51(4), 452-473.

Aklujkar, A. (2011). Unity of the Mīmāmsās: How historiography hides history. In Radha Vallabh Tripathi, et al. (Eds.), Vacaspativaibhavam. A volume in felicitation of Professor Vachaspati Upadhyaya (pp. 821-900). Delhi: D. K. Printworld. 
Aklujkar, A. (2013). Sañkarṣa-kāṇḍa: A victim in Mīmāmssā Madhyama-vyāyoga. In P. Pratap Kumar \& Jonathan Duquette (Eds.), Classical and contemporary issues in Indian studies. Essays in honour of Trichur S. Rukmani (pp. 179-210). New Delhi: D. K. Printworld.

Bapat, Shailaja (2011): A critical edition of the Brahmasütras. Sanskrit text with translation into english, critical analysis and notes, with Śañkarācārya's commentary Śārīrakamīmāṃsābhāṣya. Delhi: New Bharatiya Book Corporation.

Bronkhorst, J. (1998). Does the Veda have an author? A reply to Professor Stephen H. Phillips. Asiatische Studien/Études Asiatiques, 52(1), 5-14.

Bronkhorst, J. (2007): Vedānta as Mīmāṃsā. Mīmāmsāa and Vedānta: Interaction and Continuity. In J. Bronkhorst (Ed.) (pp. 1-91). Delhi: Motilal Banarsidass. (Papers of the 12th World Sanskrit Conference, 10.3.).

Bronkhorst, J. (2009). Buddhist teaching in India. Boston: Wisdom Publications.

Eltschinger, V., Krasser, H. \& Taber, J. (2012): Can the Veda speak? Dharmakīrti against Mìmāmsā exegetics and Vedic authority. An annotated translation of PVSV (pp. 164,24-176,16). Wien: Verlag der Österreichischen Akademie der Wissenschaften. (Österreichische Akademie der Wissenschaften, philosophisch-historische Klasse, Sitzungsberichte, 831. Band.). 